\title{
Hyperfiltration of saline water through clay-rich aquitards: chemical and isotopic evidence form a vertical profiles in the North China Plain
}

\author{
Ying Wang ${ }^{1}$, Zongyu Chen ${ }^{1}$, and Jiang Chen ${ }^{1}$ \\ ${ }^{1}$ Institute of Hydrogeology and Environmental Geology
}

November 11, 2020

\begin{abstract}
Clay aquitards are semipermeable membranes that allow groundwater flow while retarding solute migration have been researched extensively but also subjected to much debate. In this study, we collected clay samples from drilling cores (30-90m) in the Hengshui area located in the Hebei Plain, then extracted pore water using a high-pressure squeezing device. Vertical hydrochemical and isotopic profile variation trends for the pore water were revealed using hydrochemical $(\mathrm{Cl}-, \mathrm{Na}+, \mathrm{Ca} 2+$, $\mathrm{K}+, \mathrm{Mg} 2+$, and SO42-) and stable isotopic measurements of $\mathrm{H}, \mathrm{O}$, and $\mathrm{Cl}$. The results showed that the hydrochemical clay interlayer pore water of the saline aquifer is $\mathrm{Cl}^{*} \mathrm{SO} 4-\mathrm{Na} * \mathrm{Mg}$ type and the average total dissolved solids(TDS)is $10.17 \mathrm{~g} / \mathrm{L}$. The hydrochemical clay aquitard pore water is of the $\mathrm{Cl} * \mathrm{SO} 4-\mathrm{Na}{ }^{*} \mathrm{Ca}$ type with an average TDS of $1.9 \mathrm{~g} / \mathrm{L}$. The hydrochemical clay interlayer pore water of aquifer II is of $\mathrm{Cl}-\mathrm{Na}^{*} \mathrm{Ca}$ type with an average TDS of $1.1 \mathrm{~g} / \mathrm{L}$. Our results showed that the water quality of the aquifer II is not affected by the upper part of saline aquifer, thus the clay aquitard acts as a significant barrier to salt movement. A polarization layer concentrated in ions was formed between the upper part of saline aquifer and the clay aquitard. The concentration polarization layer increases the salt-inhibition effect. Isotpic $\mathrm{H}, \mathrm{O}$, and $\mathrm{Cl}$ results showed significant fractionation. The pore water of aquifer II lacked heavy isotopes(D、18O $、 37 \mathrm{Cl})$, but had significant heavy isotope enrichment in the concentrated polarized layer (the $\delta \mathrm{D}$ value was -76 was 1.59 fractionation.
\end{abstract}

\section{Hosted file}

word.pdf available at https://authorea.com/users/374936/articles/492307-hyperfiltration-ofsaline-water-through-clay-rich-aquitards-chemical-and-isotopic-evidence-form-a-verticalprofiles-in-the-north-china-plain

\section{Hosted file}

figure.pdf available at https://authorea.com/users/374936/articles/492307-hyperfiltration-ofsaline-water-through-clay-rich-aquitards-chemical-and-isotopic-evidence-form-a-verticalprofiles-in-the-north-china-plain 